\title{
Pengaruh Model Direct Instruction Berbantuan Simulasi Virtual Terhadap Penguasaan Konsep Siswa
}

\author{
${ }^{1}$ Baiq Ida Arianti, ${ }^{2}$ Hairunnisyah Sahidu, ${ }^{2}$ Ahmad Harjono, ${ }^{2}$ Gunawan \\ 1,2 Program Studi Pendidikan Fisika \\ Universitas Mataram \\ Mataram, Indonesia \\ Email: baiq idaarianti@gmail.com
}

\begin{abstract}
Abstrak--Penelitian ini merupakan jenis penelitian quasi eksperimen dengan desain non-equivalent control grup design. Pengambilan sampel dilakukan dengan teknik purposive sampling. Populasi penelitian adalah seluruh siswa kelas X MIA MAN 2 Praya. Sampel penelitian diperoleh siswa kelas X MIA-1 sebagai kelas eksperimen dan siswa kelas X MIA-2 sebagai kelas kontrol. Data penelitian dianalisis dengan uji-t polled varians dengan taraf signifikan $5 \%$, dan diperoleh hasil $t_{\text {hitung }}=2,54$ dan $t_{\text {tabel }}=2,02$. Oleh karena $t_{\text {hitung }}>t_{\text {tabel }}$, maka dapat disimpulkan bahwa model direct instruction berbantuan simulasi virtual berpengaruh terhadap penguasaan konsep fisika siswa.
\end{abstract}

Kata Kunci : Model Direct Instruction, Simulasi Virtual, Penguasaan Konsep

\section{PENDAHULUAN}

Fisika merupakan salah satu cabang IPA yang mempelajari kumpulan fakta-fakta, konsepkonsep, prinsip-prinsip dan merupakan suatu proses penemuan serta prospek pengembangan lebih lanjut dalam menerapkannya di dalam kehidupan sehari-hari. Proses penemuan konsep melibatkan keterampilan yang mendasar melalui percobaan ilmiah dapat dilaksanakan dan ditingkatkan melalui kegiatan laboratorium [1].

Pembelajaran fisika hanya sekedar tuntutan untuk menjalankan kurikulum di sekolah, tidak ada relevansinya dengan kehidupan nyata maka banyak yang ditemukan rendahnya pengetahuan peserta didik tentang fisika. Guru yang berperan sebagai pendidik bertugas mengembangkan model dan metode pembelajaran yang akan berdampak terhadap kualitas pembelajaran itu sendiri. Pada proses pembelajaran erat kaitannya dengan model dan metode pembelajaran yang digunakan oleh guru. Oleh karena itu, guru di tuntut untuk selalu menggunakaan model dan metode yang bervariasi dan disesuaikan dengan materi ajar serta kemampuan dasar yang dimiliki oleh peserta didik.

Masalah yang dihadapi dunia pendidikan kita saat ini adalah lemahnya proses pembelajaran. Dalam proses pembelajaran peserta didik kurang didorong untuk mengembangkan kemampuan berpikir, khususnya pada pembelajaran fisika. Peserta didik cenderung menghafal tanpa memahami materi serta lebih ditekankan agar pandai melakukan perhitungan. Selain itu terdapat beberapa anggapan peserta didik bahwa pelajaran fisika itu sulit karena terdapat banyak rumus yang rumit dan sulit dimengerti. Hal tersebut yang bisa menyebabkan peserta didik merasa kesulitan dalam belajar serta suasana belajar akan terasa membosankan. Oleh karena itu, guru memiliki peran membuat peserta didik mampu menguasai konsep dan melakukan proses penemuan.

Penguasaan konsep fisika sebagai salah satu aspek dalam mengukur hasil belajar peserta didik sangat penting untuk ditingkatkan. Salah satu cara yang dapat dilakukan adalah dengan menerapkan model pembelajaran yang dapat mengefektifkan penyampaian materi dan sesuai dengan tingkat kemampuan dasar peserta didik. Selain itu, model pembelajaran yang diterapkan juga dapat memberikan peserta didik pengetahuan yang saling menunjang dalam proses memahami konsep seperti pengetahuan deklaratif dan pengetahuan prosedural. Salah satu model pembelajaran yang dapat diterapkan yaitu model direct instruction.

Melalui model direct instruction, peserta didik dapat memahami konsep tanpa terjadi miskonsepsi, karena guru akan mengarahkan secara langsung materi ajar yang akan dicapai oleh peserta didik. Menurut Arends [2], model direct instruction adalah salah satu pendekatan mengajar yang dirancang khusus untuk menunjang proses 
belajar siswa yang berkaitan dengan pengetahuan deklaratif dan pengetahuan prosedural. Selain itu, model pembelajaran ini juga ditujukan untuk membantu peserta didik mempelajari keterampilan dasar dan memperoleh informasi yang dapat diajarkan selangkah demi selangkah [3].

Selain pemilihan model pembelajaran yang tepat, penggunaan metode juga berperan penting dalam proses pembelajaran. Metode pembelajaran yang digunakan dapat meningkatkan motivasi belajar peserta didik dan dapat memberikan kesempatan untuk belajar secara dinamis dan interkatif. Salah satu alternatif metode yang dapat digunakan adalah metode simulasi yakni berupa simulasi virtual. Simulasi virtual bertujuan agar peserta didik memiliki kesempatan untuk belajar dan menerapkan keterampilan dunia nyata [4]. Penggunaan simulasi virtual juga dapat memberikan solusi terhadap kondisi laboratorium yang memiliki masalah dengan alat dan bahan eksperimen. Melalui penerapan model direct instruction berbantuan simulasi virtual, diaharapkan mampu membuat peserta didik menguasai konsep-konsep fisika dengan baik. Selain itu juga, pembelajaran fisika tidak lagi dianggap sulit oleh peserta didik dan guru juga dapat memberi penjelasan dengan mudah pada materi yang dianggap rumit dan kompleks.

\section{TINJAUAN PUSTAKA}

Model direct instruction (DI) atau model pengajaran langsung merupakan salah satu model pembelajaran yang paling umum dan banyak digunakan oleh guru. Pada model direct instruction guru akan memberikan materi yang disampaikan secara langsung kepada siswa secara bertahap. Menurut Mujis \& Reynolds [5], pengajaran langsung yang juga dikenal dengan sebutan active teaching (pengajaran aktif) atau whole-class teaching (pengajaran seluruh-kelas) mengacu pada gaya mengajar dimana guru terlibat aktif dalam mengusung isi pelajaran kepada murid-muridnya dengan mengajarkan secara langsung kepada seluruh kelas. Pendapat lain disampaikan oleh Arends [2], model DI adalah salah satu pendekatan mengajar yang dirancang khusus untuk menunjang proses belajar siswa yang berkaitan dengan pengetahuan deklaratif dan pengetahuan prosedural dan terstruktur dengan baik yang dapat diajarkan dengan pola kegiatan yang bertahap. Pendapat ini dijelaskan lebih spesifik lagi oleh Arikunto [6], model pembelajaran ini ditujukan untuk membantu siswa mempelajari keterampilan dasar dan memperoleh informasi yang dapat diajarkan selangkah demi selangkah.

Model DI membutuhkan perencanaan dan pelaksanaan yang sangat hati-hati dipihak guru. Agar efektif, pembelajaran langsung mensyaratkan tiap detail keterampilan atau isi didefinisikan secara seksama dan demonstrasi serta jadwal pelatihan direncanakan dan dilaksanakan secara seksama.

Alur atau sintaks model DI dijelaskan oleh Arikunto [6], antara lain: (1) Menyampaikan tujuan dan mempersiapkan siswa. Guru menjelaskan TPK, informasi latar belakang pelajaran, pentingnya pelajaran, mempersiapkan siswa untuk belajar; (2) Mendemonstrasikan pengetahuan dan keterampilan. Guru mendemonstrasikan keterampilan dengan benar, atau menyajikan informasi tahap demi tahap; (3) Membimbing pelatihan. Guru merencanakan dan memberi bimbingan pelatihan awal; (4) Mengecek pemahaman dan memberikan umpan balik. Mengecek apakah siswa telah berhasil melakukan tugas dengan baik, memberi umpan balik; (5) Memberikan kesempatan untuk pelatihan lanjutan dan penerapan. Guru mempersiapkan kesempatan melakukan pelatihan lanjutan dengan perhatian khusus pada penerapan kepada situasi lebih kompleks dalam kehidupan sehari-hari.

Selain pemilihan model pembelajaran yang tepat, penggunaan metode juga berperan penting dalam proses pembelajaran. Salah satu alternatif metode yang dapat digunakan yaitu metode simulasi yakni berupa simulasi virtual. Dalam penelitian ini, komputer digunakan sebagai media untuk menerapkan simulasi virtual. Menurut Gunawan [4], simulasi virtual adalah sebuah simulasi komputer yang memungkinkan fungsifungsi penting dalam percobaan laboratorium untuk dilaksanakan pada komputer. Dengan simulasi virtual, lingkungan yang kompleks dapat ditata menyerupai dunia nyata [7]. Selain itu, Gunawan [4] mengatakan bahwa "penggunaan multimedia memungkinkan guru dan siswa untuk mengintegrasikan, menggabungkan dan berinteraksi dengan media untuk mendukung proses pembelajaran yang akan dilaksanakan".

Secara umum, simulasi virtual dimaksudkan untuk mentransfer pengetahuan baik konseptual 
maupun prosedural. Simulasi virtual bisa digunakan untuk melakukan kegiatan eksperimen atau demonstrasi. Sebagaimana yang telah dijelaskan oleh Gunawan, et al [8] dari hasil penelitiannya dapat disimpulkan keuntungan melakukan kegiatan eksperimen menggunakan simulasi virtual antara lain : kegiatan praktikum menjadi lebih efisien dan murah karena setiap tahapan percobaan sudah tersedia dalam software pembelajaran, tidak memerlukan biaya perawatan yang mahal, kegiatan praktikum menjadi lebih aman karena tidak ada gangguan yang dapat membahayakan praktikan. Selain itu, praktikum berbantuan teknologi komputer terbukti telah mampu meningkatkan keterampilan berpikir generik, keterampilan dan disposisi berpikir kritis, kemampuan pemecahan masalah, serta penguasaan konsep fisika, khususnya pada materi yang abstrak [4].

Simulasi virtual yang digunakan berupa simulasi yang sudah ada yakni program Phet Interactive Simulations yang telah dipatenkan oleh Universitas Colorado. Penggunaan simulasi pada pembelajaran lebih ditekankan untuk melakukan demontrasi oleh guru dan siswa. Fisika yang termasuk salah satu cabang IPA (sains) pada hakikatnya merupakan kumpulan pengetahuan yang berupa fakta-fakta, konsep-konsep atau prinsip-prinsip serta merupakan proses penemuan. Berdasarkan hal tersebut, penguasaan konsep yang merupakan salah satu bagian dari hakikat pembelajaran fisika penting untuk ditingkatkan.

Kata "penguasaan" menurut KBBI adalah kemampuan atau kesanggupan (untuk berbuat sesuatu). Sedangkan, kata "konsep" menurut KBBI berarti rancangan. Berdasarkan definisi tersebut, jika dikaitkan dengan pembelajaran fisika, penguasaan merupakan kemampuan dalam memahami materi fisika serta kesanggupan menggunakan pengetahuan dan kepandaian untuk diaplikasikan, sedangkan konsep merupakan rancangan yang berwujud pengertian-pengertian baru yang dapat timbul sebagai hasil pemikiran, meliputi definisi, pengertian, ciri khusus, hakikat, inti atau isi dan sebagainya. Jadi, penguasaan konsep adalah kemampuan peserta didik untuk memahami konsep-konsep suatu materi pembelajaran baik secara teori maupun penerapannya dalam kehidupan sehari-hari.

Pendapat lain menurut Dahar [9], penguasaan konsep sebagai kemampuan siswa dalam memahami makna secara ilmiah baik teori maupun penerapannya dalam kehidupan seharihari. Keberhasilan penguasaan konsep dapat diukur berdasarkan hasil belajar ranah kognitif menurut takstonomi Bloom yang mencakup $\mathrm{C} 1$ (mengingat), C2 (memahami), C3 (mengaplikasi), C4 (menganalisis), C5 (mengevaluasi) dan C6 (mencipta).

\section{METODE PENELITIAN}

Penelitian ini merupakan penelitian quasi eksperimen dengan desain non-equivalent control grup design. Peneltian dilakukan di MAN 2 Praya dan kegiatan penelitian berlangsung selama 12 bulan dimulai dari Oktober 2015 sampai September 2016. Subjek penelitian adalah siswa kelas X-MIA ${ }^{1}$ sebanyak 25 orang (kelas eksperimen) dan $\mathrm{X}^{-\mathrm{MIA}^{2}}$ sebanyak 23 orang (kelas kontrol). Instrumen yang digunakan berbentuk pilihan ganda sebanyak 20 soal yang mencakup C1 sampai C6. Analisis data diawali dengan menghitung uji normalitas dan uji homogenitas. Selanjutnya, dilakukan uji beda nilai rata-rata hasil tes penguasaan konsep fisika untuk kedua kelas dengan menggunakan t-test polled varians. Dalam rangka antisipasi kesalahan penafsiran perbedaan peningkatan nilai rata-rata, juga dihitung skor gain ternormalisasi ( $\mathrm{N}$-gain) setiap siswa dengan menggunakan rumus:

$$
\mathrm{N}-\text { gain }=\frac{\mathrm{S}_{\text {post }}-\mathrm{S}_{\text {pre }}}{\mathrm{S}_{\max }-\mathrm{S}_{\text {pre }}} \times 100 \%
$$

\section{HASIL DAN PEMBAHASAN}

Keberhasilan siswa dalam menguasai konsep dapat diketahui melalui penilaian hasil belajar. Penilaian yang dapat dilakukan berupa hasil belajar ranah kognitif yang mencakup $\mathrm{C} 1$ sampai C6. Berdasarkan hasil uji homogenitas dan normalitas menunjukkan bahwa data berasal dari populasi yang homogen dan terdistribusi normal. Data hasil tes awal dan tes akhir penguasaan konsep fisika siswa kelas kontrol dan kelas eksperimen terdapat pada tabel 1. 
Tabel 1. Hasil Tes Awal dan Tes Akhir Penguasaan Konsep

\begin{tabular}{ccccccc}
\hline Kelas & Tes & Jumlah & $\begin{array}{c}\text { Nilai } \\
\text { Terendah }\end{array}$ & $\begin{array}{c}\text { Nilai } \\
\text { Tertinggi }\end{array}$ & $\begin{array}{c}\text { Rata- } \\
\text { Rata }\end{array}$ & $\begin{array}{c}\text { Standar } \\
\text { Deviasi }\end{array}$ \\
\hline \multirow{2}{*}{ Eksperimen } & awal & 25 & 20 & 60 & 35,32 & 10,75 \\
& Akhir & 25 & 40 & 90 & 65,96 & 13,77 \\
\multirow{2}{*}{ Kontrol } & awal & 23 & 20 & 55 & 33,98 & 9,21 \\
& akhir & 23 & 35 & 85 & 56,22 & 12,7 \\
\hline
\end{tabular}

Berdasarkan tabel 1, nilai rata-rata tes akhir kelas eksperimen lebih tinggi dari pada kelas kontrol. Meskipun demikian, kelas eksperimen maupun kelas kontrol mengalami peningkatan dalam menguasai konsep fisika. Kelas eksperimen mengalami peningkatan sebesar 30,64 dan kelas kontrol meningkat sebesar 22,24. Hasil tersebut menunjukkan bahwa kemampuan siswa dalam menguasai konsep fisika lebih baik di kelas eksperimen. Persentase peningkatan penguasaan konsep siswa berdasarkan perolehan nilai siswa setiap sub materi untuk kelas eksperimen dan kelas kontrol disajikan pada gambar 1.

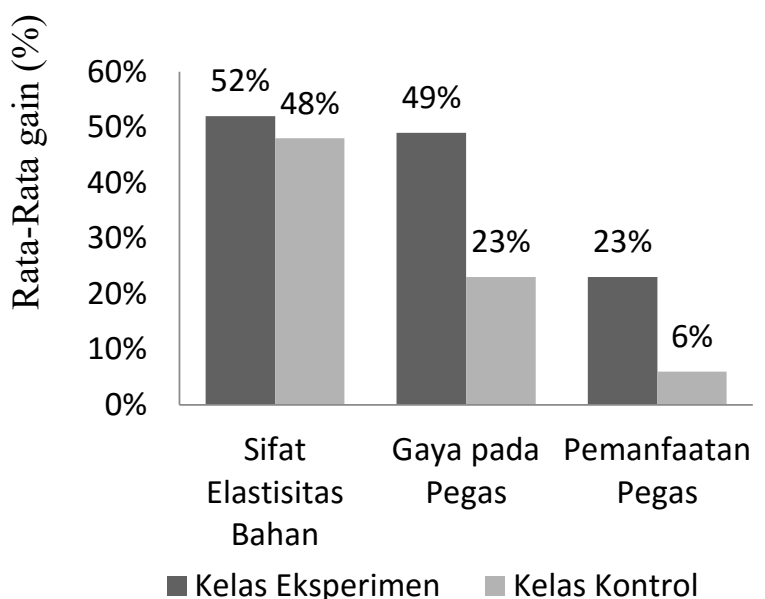

disebabkan karena dalam proses pembelajaran guru dapat terlibat aktif dalam membimbing siswa untuk memahami materi ajar secara bertahap. Pengetahuan yang diberikan berupa pengetahuan deklaratif dan pengetahuan prosedural yang mampu menunjang siswa dalam proses memahami konsep. Selain itu, guru juga dapat memberikan penekanan pada konsep yang penting dengan memberikan penjelasan menggunakan bahasa yang lebih mudah dipahami oleh siswa. Di dalam tahap model pdthalseil ajiatainisis ujii, $\mathrm{N}$-ggumusetidpnsubsinsateri

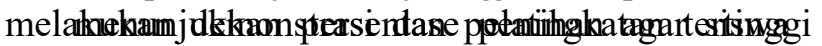

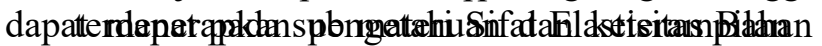

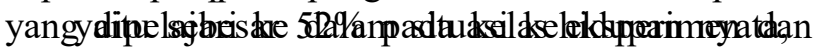

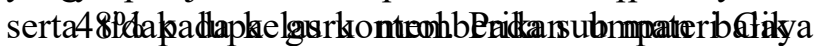
untukadameProgasasikelsisw wksplammemempentralikini

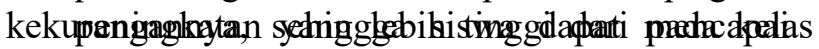
pengkarstral.koPselp ydaegamarekzperimen persentase pePièngkappan sobdsar D49?tapdanmkeilangklatinanol kemsepesan S233\%\%.dalPamberdenguapenkikgksetarfisikang

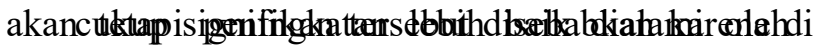

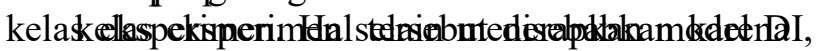

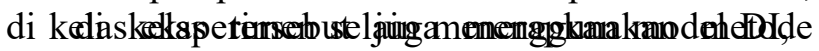

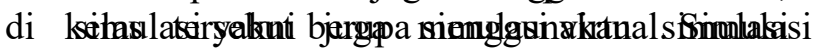
virturitrtual digunakan untuk mendemonstrasikan percaoblbaan\& HuAulingantlbok $\notin 10 j a n$ mepgatalbaran peneSassarmammereds. pengajaran langsung dengan mengintegrasikan pendekatan keterampilan proses

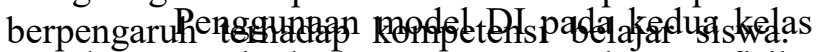

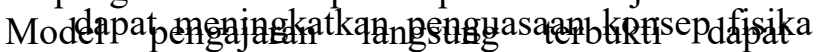

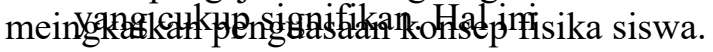

Suhandi, et al [11], menyimpulkan bahwa penggunaan simulasi virtual pada pendekatan pembelajaran konseptual interaktif dapat lebih meningkatkan efektifitasnya dalam meningkatkan pemahaman konsep siswa dan meminimalkan miskonsepsi. Penggunaan simulasi virtual dalam pembelajaran dapat memberikan siswa pengalaman untuk menemukan konsep itu sendiri.

Sumargo dan Yuanita [12], hasil penelitiannya menunjukkan bahwa keterlaksanaan pembelajaran dengan menerapan media pembelajaran laboratorium virtual (Phet) pada materi laju reaksi dengan model pengajaran langsung dinyatakan baik dan aktivitas belajar siswa tinggi. Hasil penelitian ini menunjukkan bahwa penerapan model Direct Instruction (pengajaran langsung) berbantuan simulasi virtual 
berpengaruh terhadap penguasaan konsep fisika siswa.

\section{SIMPULAN}

Hasil penelitian menunjukan bahwa penguasaan konsep fisika siswa yang diajarkan dengan menggunakan model direct instruction berbantuan simulasi virtual lebih tinggi dibandingkan dengan siswa yang diajarkan dengan hanya menerapkan model direct instruction. Berdasarkan hasil tersebut dapat disimpulkan bahwa penerapan model direct instruction berbantuan simulasi virtual berpengaruh terhadap penguasaan konsep siswa.

\section{UCAPAN TERIMA KASIH}

Terima kasih disampaikan kepada Tim Hibah Penelitian Strategis Nasional Kemenristek Dikti Tahun 2016 yang telah melibatkan kami dalam penelitiannya, membimbing dan mengajarkan banyak hal, serta memfasilitasi semua proses hingga publikasi ilmiah bersama.

\section{REFERENSI}

[1] Depdiknas. 2006. Standar Isi untuk Satuan Pendidikan Dasar dan Menengah. Jakarta: Badan Standar Nasional Pendidikan.

[2] Arends, R. 2008. Learning to Teach-Belajar untuk Mengajar. Yogyakarta: Pustaka Belajar.

[3] Trianto. 2012. Model Pembelajran Terpadu Dalam Teori dan Praktik. Jakarta: Prestasi Pustaka.

[4] Gunawan. 2015. Model Pembelajaran Sains Berbasis ICT. Mataram: FKIP UNRAM.

[5] Mujis, D. \& Reynolds. D. 2008. Efeective Teaching Teori dan Aplikasi. Jakarta: Pustaka Pelajar.

[6] Arikunto, S. 2014. Prosedur Penelitian: Suatu Pendekatan Praktik. Jakarta: Rineka Cipta.

[7] Arsyad, A. 2011. Media Pembelajaran. Jakarta: Raja Grafindo Persada.

[8] Gunawan., Setiawan. A. \& Widyantoro, D.H. 2013. Model Virtual Laboratory Fisika
Modern untuk Meningkatkan Keterampilan Generik Sains Calon Guru. Jurnal Pendidikan dan Pembelajaran. Vol. 20, No. 1: 25-32.

[9] Dahar, R.W.. 2003. Teori-Teori Belajar. Jakarta: Gelora Aksara Prima.

[10] Laili, S.W.D. \& Suliyanah. 2013. Pengaruh Penerapan Model Pengajaran Langsung dengan Mengintegrasikan Pendekatan Keterampilan Proses terhadap Kompetensi Belajar Siswa Kelas X Semester II SMAN 1 Wonoayu. Jurnal Inovasi Pendidikan Fisika. Vol. 02, No. 03: 80-84.

[11] Suhandi. A., Sinaga. I., Kaniawati. E. \& Suhendi. 2009. Efektifitas Penggunaan Media Simulasi Virtual pada Pendekatan Pembelajaran Konseptual Interaktif dalam Meningkatkan Pemahaman Konsep dan Mengurangi Miskonsepsi. Jurnal Pendidikan Fisika FPMIPA UPI. Tersedia di. konsep fisika :

http://repository.upi.ac.id/487/ (diakses tanggal 15 maret 2016).

[12] Sumargo, E. \& Yuanita. L. 2014. Penerapan Media Laboratorium Virtual (Phet) pada Materi Laju Reaksi dengan Model Pengajaran Langsung. Unesa Journal of Chemical Education. Vol. 3, No. 1 : 119133.

\section{Biografi Penulis}

Baiq Ida Arianti, lahir di Batutulis 12 Januari 1995. Tahun 2012 lulus di MAN 2 Praya dan melanjutkan pendidikan S-1 di Universitas Mataram pada program studi pendidikan fisika hingga meraih gelar sarjana pendidikan pada tahun 2016. 